\title{
CELl CULTURE PROPAgation OF BOVINE CORONAVIRUS
}

\author{
Linda J. Saif, Robert A. Heckert, Kathy L. Miller, \\ and Mohamed M. Tarek

\begin{abstract}
Food Animal Health Research Program, Ohio Agricultural Research and Development Center, Ohio State University, Wooster, Ohio 44691, Ohio; and Department of Parasitology and Microbiology

(M. M. T.), Faculty of Medicine, Zagazig University, Zagazig, Egypt
\end{abstract}

\begin{abstract}
SUMMARY: Although most field strains of bovine coronavirus (BCV) grow poorly in cell culture and fail to produce cytopathic effects (CPE) until after blind passage, primary calf kidney (PCK) and Vero cells have permitted primary isolation of virus. Cell culture-adapted strains of BCV replicate in PCK, bovine embryonic lung, bovine fetal thyroid, bovine fetal brain, bovine skin cells, ovine fetal kidney cells, and the cell lines pig kidney K3 and 15, Vero, human embryonic lung fibroblasts, HRT-18, MDBK and BEK-1, with trypsin useful for enhancing replication. Organ culture as well as suckling mouse, rat, and hamster brains also support the growth of cell culture-adapted BCV strains. Viral growth is most commonly detected by CPE, immunofluorescence, hemagglutination, and hemadsorption assays or electron microscopy of supernatants from infected cells. In this report, the optimal conditions for the growth and plaque assay of the NCDV strain of BCV in MDBK cells are described.
\end{abstract}

Key words: bovine coronavirus; cell culture; propagation.

\section{INTRODUCTION}

The coronaviruses were first recognized and morphologically defined as a group by Tyrrell et al., (39-41) but have have been known by other names for almost 5 decades (33). The Coronaviridae is a monogeneric family comprising 11 viruses that infect vertebrates (29).

Stair et al. (30) first described the isolation and partial characterization of a coronavirus-like agent from calves with diarrhea. The viral particles were 107 to $160 \mathrm{~nm}$, polymorphic, and had an 11-nm petal-shaped fringe. Sharpee et al. (28) further characterized this coronavirus-like agent and showed that it possessed all six major properties common to members of the Coronaviridae family. The virion is composed of four proteins and possesses a lipid bilayer. The genome consists of a single-stranded polyadeylated RNA which is infectious and of positive polarity.

Bovine coronavirus (BCV) causes severe diarrhea in calves 3 to $30-\mathrm{d}$ old which can result in death due to dehydration and acidosis $(18,24,30)$. In addition to enteric replication of $\mathrm{BCV}$, several workers have reported respiratory replication and clinical signs of upper respiratory infection. Thomas et al. (37) first reported the isolation of coronavirus from the respiratory tract of several calves showing respiratory illness. Since then other workers have detected bovine coronavirus upper respiratory infections, both in experimental and field situations $(5,21,25,26)$.
In this report, the optimal cell culture conditions for the growth and plaque assay of the NCDV (Mebus) strain of BCV in MDBK cells are described. Also included is a review of the literature pertaining to the cultivation of $\mathrm{BCV} \mathrm{s}$ in cell and organ cultures.

\section{I. MATERIALS}

A. Equipment

Vortex Mixer, model K-550-G, Scientific Industries ${ }^{1}$ Incubator, $32 \mathrm{ft}^{3}$, National Appliance ${ }^{2}$ Incubator, $\mathrm{CO}_{2}$, model 2220, Queue Systems ${ }^{3}$ Waterbath, no. 66648, Precision Scientific ${ }^{4}$ Laminar flow hood, Edgegard, Baker Company Wheaton Roller Culture Apparatus, Wheaton ${ }^{6}$ Seitz filter, Republic ${ }^{7}$ Millipore Filter, Millipore ${ }^{8}$

B. Chemicals Mycostatin (Nystatin) $500000 \mathrm{U}$, Squibb $^{9}$ Penicillin G potassium NDC 0995-0510-95, Pfizer $^{10}$ Dihydrostreptomycin sulfate 100405, NB Co. ${ }^{11}$ MEM medium, no. 410-1500, GIBCO ${ }^{12}$ $\mathrm{NaHCO}_{3}$, no. S-233, Fisher Scientific ${ }^{13}$ HCL, HX0603-3, Matheson Coleman \& Bell ${ }^{14}$ $\mathrm{NaCl}$, no. S-271 ${ }^{13}$

KCL, no. P-217 13

$\mathrm{MgSO}_{4} \cdot 7 \mathrm{H}_{2} \mathrm{O}$, no. $\mathrm{M}-63^{13}$

$\mathrm{CaCl}_{2}$, no. C-614 $4^{13}$

$\mathrm{Na}_{2} \mathrm{HPO}_{4} \cdot 7 \mathrm{H}_{2} \mathrm{O}$, no. $\mathrm{S}-373^{13}$ 
$\mathrm{KH}_{2} \mathrm{PO}_{4}$, no. $73351, \mathrm{Merck}^{15}$

Chloroform, no. C-298 ${ }^{13}$

Dextrose, Anhydrous, Granular, no. DV145 CB361 ${ }^{14}$

Disodium salt of ethylenediamine tetraacetate acid (Versene) no. S-311 ${ }^{13}$

Trypsin (1:250) no. 840-72501 $\mathrm{M}^{12}$

Neutral Red, no. B360 ${ }^{14}$

Phenol red sodium salt, no. P-391 ${ }^{13}$

Pancreatin $4 \times$ NF, $2.5 \%(10 \times)^{12}$

$\mathrm{NaH}_{2} \mathrm{PO}_{4} \cdot \mathrm{H}_{2} \mathrm{O}$, no. S-368

Agar Noble, no. 0142-01, Difco ${ }^{16}$

C. Supplies

Tissue culture cluster, no. 3506, Costar ${ }^{17}$

Roller Bottles ${ }^{6}$

T-150 $\mathrm{cm}^{2}$ Falcon 3028, Becton Dickinson ${ }^{18}$

Fetal Bovine Serum (FBS), Qualified, 200-2640 AJ $^{12}$

D. Cells

Madin-Darby Bovine Kidney (MDBK), Salisbury Laboratories $^{19}$

\section{PROCEDURE}

A. Preparation of solutions

1. Antibiotic stock solution $(100 \times)$

10 vials 1 -million $U$ each, penicillin (for injection, stored at room temperature)

$10 \mathrm{~g}$ dihydrostreptomycin sulfate (not for drug use) (store $4^{\circ} \mathrm{C}$ )

5 vials $\quad 500000-\mathrm{U}$ each, mycostating (store $4^{\circ}$ C)

To make $1000 \mathrm{ml}$ of stock solution

a. Dissolve $10 \mathrm{~g}$ of dihydrostreptomycin in $100 \mathrm{ml}$ sterile Hanks' balanced salt solution (HBSS), sterilize with $0.20-\mu \mathrm{m}$ Nalge filter.

b. With a syringe and needle, aspirate 2 to $3 \mathrm{ml}$ of HBSS (of remaining $900 \mathrm{ml}$ HBSS) and use to dissolve the powdered contents of all vials of penicillin and mycostatin. Expel into 1000-ml flask.

c. Combine all ingredients and mix well.

d. Dispense into 2-oz. bottles.

e. Store in a frozen state.

$\begin{array}{lc} & \begin{array}{c}\text { each cc of above } \\ 100 \times \text { stock solution }\end{array} \\ \text { Penicillin } & 10000 \mathrm{U} \\ \text { Dihydrostreptomycin } & 10000 \mu \mathrm{g} \\ \text { Mycostatin } & 500 \mathrm{U}\end{array}$

2. $0.01 M$ Phosphate buffered saline (PBS) (0.14 M

$\mathrm{NaCl}), \mathrm{pH} 7.4$

a. Dissolve the following up to 2 liter in $2 \times$ distilled water $\mathrm{DH}_{2} \mathrm{O}$.

$\mathrm{NaH}_{2} \mathrm{PO}_{4} \cdot \mathrm{H}_{2} \mathrm{O} \quad 0.78 \mathrm{~g}$

$\mathrm{Na}_{2} \mathrm{PO}_{4} \cdot 7 \mathrm{H}_{2} \mathrm{O} \quad 3.85 \mathrm{~g}$

$\mathrm{NaCl} \quad 16.40 \mathrm{~g}$

b. Sterilize by autoclaving $15 \mathrm{~min}$, slow exhaust

3. Pancreatin $4 \times N / F$

a. Stock $(10 \times)$ : $25 \mathrm{~g}$ pancreatin $4 \times \mathrm{NF}$ and $8.5 \mathrm{~g}$ $\mathrm{NaCl} /$ liter

b. Pancreatin $(10 \times)$ is diluted $1: 10$ with PBS, pH 7.4 , and stored at $-20^{\circ} \mathrm{C}$ as the $1 \times$ stock.

4. Sodium bicarbonate $\left(\mathrm{NaHCO}_{3}\right)$ solution.

a. $7 \%$ Solution is routinely used in our laboratory. i. Add $70 \mathrm{~g} \mathrm{NaHCO}_{3}$ to a 2000 -ml Erlenmeyer flask.

ii. Add $930 \mathrm{ml}$ of distilled water $\left(\mathrm{DH}_{2} \mathrm{O}\right)$.

iii. Dissolve. To facilitate or to shorten the time necessary, a magnetic mixer may be used.

iv. Sterilize using S-99 filter.

v. Dispense in sterile 4-oz. bottles. Screw the caps on tight and then tape the caps with masking tape to prevent loss of $\mathrm{CO}_{2}$. Store at $4^{\circ} \mathrm{C}$

5. Neutral red (NR) solution (1:1000)

a. Weigh out $1.0 \mathrm{~g}$ of $\mathrm{NR}$ and add to $1000 \mathrm{ml}$ deionized water. Mix well.

b. Dispense into 4-oz. bottles.

c. Autoclave at $15 \mathrm{lb}$ for $20 \mathrm{~min}$, then screw the caps tight and seal with tape.

6. HBSS

This salt solution is commonly employed as one of the basic solutions in the cultivation or maintenance of cell cultures. The method described below for the preparation of this solution is a slight modification of the method described by Weller et al (43).

a. Stock solution $A-$ for $1000 \mathrm{ml}$

i. Weigh out the following and place in a large, clean flask

$\begin{array}{lr}\mathrm{NaCl} & 160 \mathrm{~g} \\ \mathrm{KCl} & 8 \mathrm{~g} \\ \mathrm{MgSO}_{4} \cdot 7 \mathrm{H}_{2} \mathrm{O} & 4 \mathrm{~g}\end{array}$

ii. Dissolve these salts in approximately $800 \mathrm{ml}$ of $\mathrm{DH}_{2} \mathrm{O}$.

iii. Dissolve $2.8 \mathrm{gms}$ of $\mathrm{CaCl}_{2}$ in approximately $100 \mathrm{ml} \mathrm{DH}_{2} \mathrm{O}$.

iv. Combine these two solutions in a $1000-\mathrm{ml}$ graduate cylinder, and make up to $1000 \mathrm{ml}$ with $\mathrm{DH}_{2} \mathrm{O}$.

v. Add $2 \mathrm{ml}$ of chloroform as a preservative.

vi. Place the solution in a suitable container, such as a large bottle; cap and store at $4^{\circ} \mathrm{C}$.

b. Stock solution B-for $1000 \mathrm{ml}$

i. Weigh out the following and place in a large clean flask:

$\mathrm{Na}_{2} \mathrm{HPO}_{4} \cdot 7 \mathrm{H}_{2} \mathrm{O} \quad 2.2 \mathrm{~g}$

$\mathrm{KH}_{2} \mathrm{PO}_{4} \quad 1.2 \mathrm{~g}$

Dextrose $\quad 20.0 \mathrm{~g}$

ii. Dissolve in approximately $800 \mathrm{ml} \mathrm{DH}_{2} \mathrm{O}$.

iii. Add $100 \mathrm{ml}$ of $0.4 \%$ phenol red solution. It may be prepared as follows: weigh out $1 \mathrm{~g}$ of the water-soluble (sodium salt) phenol red indicator and dissolve in $250 \mathrm{ml} \mathrm{DH}_{2} \mathrm{O}$. Adjust the $\mathrm{pH}$ to $7 \mathrm{by}$ addition of either $0.1 \mathrm{~N}$ $\mathrm{HCl}$ or $0.1 N \mathrm{NaOH}$.

iv. Add $2 \mathrm{ml}$ of chloroform to stock solution $B$ as a preservative.

v. Place stock solution B in a $1000-\mathrm{ml}$ graduate cylinder, and make up to $1000 \mathrm{ml}$ with $\mathrm{DH}_{2} \mathrm{O}$.

vi. Place the solution in a suitable container, such as a large bottle, cap and store at $4^{\circ} \mathrm{C}$.

c. The complete HBSS ( $\mathrm{pH}$ adjusted to 6.5) 
i. Add the following to a suitable container:

- 1 part stock solution A, $150 \mathrm{ml}$

- 1 part stock solution B, $150 \mathrm{ml}$

- 18 parts $\mathrm{DH}_{2} \mathrm{O}$

- Plus about $0.6 \mathrm{ml}$ of $1 N \mathrm{HCl} / 3000 \mathrm{ml}$ solution to bring $\mathrm{pH}$ to about 6.5 . In our laboratory, several thousand milliliter of the solution is prepared and then dispensed in $300-\mathrm{ml}$ amounts in $16 \mathrm{oz}$ bottles or other suitable containers.

ii. Autoclave at $\mathbf{1 5} \mathrm{lb}$ pressure for $15 \mathrm{~min}$. If a precipitate occurs when autoclaving this can be subsequently prevented by the addition of $0.6 \mathrm{ml}$ of $1 \mathrm{~N} \mathrm{HCl}$ to reduce the $\mathrm{pH}$ to about 6.5 before autoclaving. Amount depends on color.

iii. The solution is stored at $4^{\circ} \mathrm{C}$.

iv. Before use, the pH of the HBSS is increased to the desired point by the addition of sterile $\mathrm{NaHCO}_{3}$ solution (pH 7.2). In our laboratory a $7 \%$ stock solution is used which has been sterilized by filtration through a Seitz filter using positive pressure.

7. Preparation of Alkaline Trypsin Versene (ATV)

$\begin{array}{lc}\mathrm{NaCl} & 8.0 \mathrm{~g} \\ \mathrm{KCL} & 0.4 \mathrm{~g} \\ \mathrm{NaHCO}_{3} & 0.58 \mathrm{~g} \\ \text { Trypsin }(1: 250) & 0.5 \mathrm{~g} \\ \text { porcine parvovirus tested } & \\ \quad \text { Versene } & 0.2 \mathrm{~g} \\ \quad \text { Dextrose } & 1.0 \mathrm{~g} \\ \quad \mathrm{DH}_{2} \mathrm{O} & 1000 \mathrm{ml}\end{array}$

$0.20-\mu \mathrm{m}$ Seitz filter to sterilize, and store frozen.

8. Growth medium
a. MEM (prepared without $\mathrm{NaHCO}_{3}$ before filtering)
b. $5 \%$ fetal bovine serum (FBS)
c. $2 \% \mathrm{NaHCO}_{3}$
d. $1 \%$ antibiotics $(100 \times)$
e. $0.1 \%(0.1 \mathrm{~N}) \mathrm{HCl}$

9. Diluent no. 5 .
a. MEM
b. $1 \% \mathrm{NaHCO}_{3}$
c. $1 \%$ antibiotics $(100 \times)$

10. Agar overlay medium. Measure out $1.6 \%$ Noble agar, mix with $\mathrm{DH}_{2} \mathrm{O}$, and boil to melt for $20 \mathrm{~min}$, then cool to $42^{\circ} \mathrm{C}$ and add equal volume of $2 X$ MEM plus:

$3 \% \mathrm{NaHCO}_{3}(7 \%$ stock $)$

$1 \%$ antibiotics $(100 \times)$

$0.7 \%(0.1 \%)$ NR

$1 \%$ Pancreatin (1:40)

11. MEM

$1 \%$ DEAE $(100 \mu \mathrm{g} / \mathrm{ml})$

a. Weigh out $9.8 \mathrm{~g} /$ liter of $\mathrm{MEM}$ powder and dissolve in double $\left(\mathrm{DDH}_{2} \mathrm{O}\right)$.

b. Filter MEM through $0.22-\mu \mathrm{m}$ Millipore filter

c. Store MEM at $4^{\circ} \mathrm{C}$.

12. $2 \times \mathrm{MEM}$ a. Weigh out $19.6 \mathrm{~g} /$ liter of MEM powder and dissolve in $\mathrm{DDH}_{2} \mathrm{O}$.

b. Filter $2 \times$ MEM through $0.22-\mu \mathrm{m}$ Millipore filter c. Store $2 \times \mathrm{MEM}$ at $4^{\circ} \mathrm{C}$

B. Propagation of the NCDV strain of BCV in MDBK cells

1. Subculture 7-d-old culture of MDBK cells using ATV. Dilute the subcultured cells 1:16 with growth medium.

2. Dispense $200 \mathrm{ml}$ of diluted cells into $900-\mathrm{cm}^{2}$ roller bottles and place in a roller culture apparatus at 80 rpm for $24 \mathrm{~h}$ at $37^{\circ} \mathrm{C}$. After $24 \mathrm{~h}$, turn speed up to $200 \mathrm{rpm}$. Allow cells to grow 5 to $6 \mathrm{~d}$. MDBK cells can overgrow very quickly causing the cell layer to peel off.

3. At 5 to $6 \mathrm{~d}$ of age, rinse the cell layer once with diluent no. 5 and change media with diluent no. 5 warmed to $37^{\circ} \mathrm{C}, 3 \mathrm{~h}$ before inoculation.

4. Inoculate each roller bottle with final volume of 30 $\mathrm{ml}$ of $\mathrm{BCV}$ (initial titer of approximately $10^{7}$ plaque-forming units $(\mathrm{pfu} / \mathrm{ml})$ diluted $1: 5$ in diluent no. 5 . Roller bottles are again placed on the roller culture apparatus at $80 \mathrm{rpm}$ for $1 \mathrm{~h}$ at $37^{\circ} \mathrm{C}$.

5. After $1 \mathrm{~h}$ the cell monolayers are rinsed once with diluent no. 5. Place $200 \mathrm{ml}$ diluent no. 5 in each roller bottle and add $480 \mu \mathrm{l}$ of Pancreatin (1X) diluted 1:40. Place bottles on roller culture apparatus at $200 \mathrm{rpm}$ at $37^{\circ} \mathrm{C}$.

6. Allow cytopathic effects (CPE) to develop to 40 to $70 \%$ ( 2 to $3 \mathrm{~d})$, and freeze roller bottles.

7. Thaw roller bottles and centrifuge the virus-cell suspensions at $2000 \mathrm{rpm}$ for $30 \mathrm{~min}$ at $10^{\circ} \mathrm{C}$.

8. Remove supernatant, dispense, and freeze at $-70^{\circ}$. Titer virus in plaque assay. Generally this procedure results in virus titers of $10^{7}$ to $10^{8}$ $\mathrm{pfu} / \mathrm{ml}$. An electron micrograph of typical BCV particles (NCDV strain) grown in MDBK cells is shown in Fig. 1.

C. Procedures for determining virus titers and neutralizing

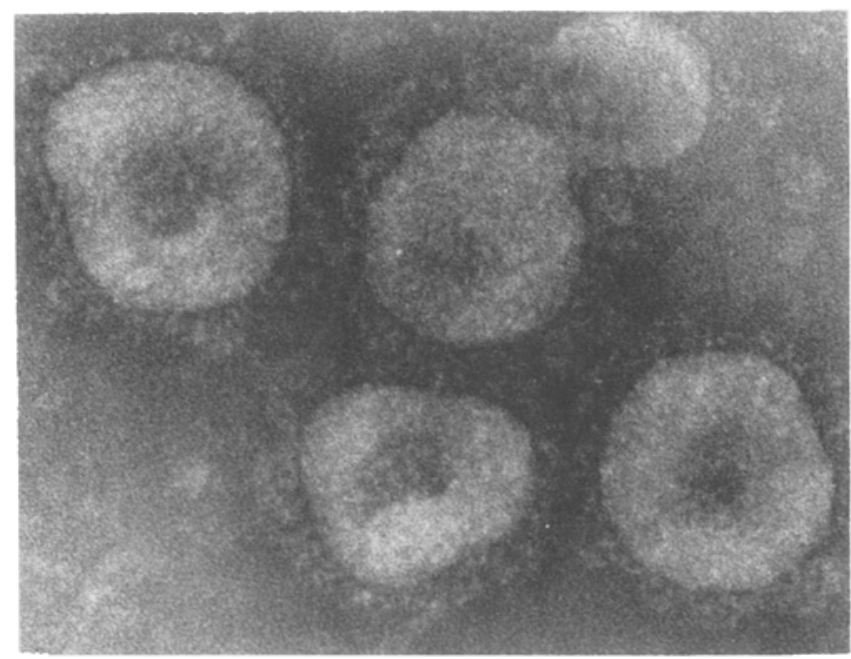

FIt. 1. Electron micrograph of an aggregate of $\mathrm{BCV}$ particles (NCDV strain) grown in MDBK cells, and reacted with calf anticoronavirus serum. $\times 195000$. 
antibodies against BCV using the plaque reduction assay with constant-virus varying serum.

1. Virus-a cell culture-adapted strain of BCV.

2. Cell culture-MDBK continuous cell line. Cells are grown in 6-well Costar plastic plates in growth medium.

3. Make fourfold serial dilutions of heat-inactivated serum samples to be tested for antibodies using diluent no. 5 .

4. Add an equal volume of the virus dilution (containing 30 to $50 \mathrm{pfu} / 0.1 \mathrm{ml}$ ) to the serum dilutions and virus control tube containing diluent no. 5 only. Mix well.

5. Place serum-virus mixture in a $37^{\circ} \mathrm{C}$ incubator for $90 \mathrm{~min}$ (neutralization period).

6. Empty fluid from 6-well plates containing MDBK cell monlayers which were rinsed $1 \times$ and media (diluent no. 5) changed $3 \mathrm{~h}$ before inoculation.

7. Inoculate $0.1 \mathrm{ml} /$ well to duplicate wells.

8. Place plates at $37^{\circ} \mathrm{C}$, in $7 \% \mathrm{CO}_{2}$ for $60 \mathrm{~min}$; rotate plates every $15 \mathrm{~min}$.

9. Cool agar overlay medium to $42^{\circ} \mathrm{C}$ and dispense approximately $3 \mathrm{ml} /$ well.

10. Protect plates from light at room temperature while agar solidifies for 15 to $30 \mathrm{~min}$.

11. Invert plates gently with agar side up and place plates in an incubator at $37^{\circ} \mathrm{C}$ in $7 \% \mathrm{CO}_{2}$ and at least $85 \%$ humidity. Plaques will appear within 3 or $4 \mathrm{~d}$.

12. For virus titration, serial 10 -fold dilutions of the virus are made in diluent no. 5 , and the rest of the test conducted according to steps 6 through 11 .

13. The virus titer is determined by counting the number of plaques per well and multiplying the average number of plaques by the final dilution of the virus to give the total pfu per milliliter.

14. The antibody titer is expressed as the reciprocal of the dilution of serum which results in a plaque reduction of $80 \%$, as compared to the virus control.

\section{DISCUSSION}

A. Cell and organ culture propagation of BCV

Mebus et al. (22) in 1973 first demonstrated that a coronavirus-like agent isolated from a calf with diarrhea could be adapted to grow in cell culture. The agent was first isolated in primary fetal bovine kidney cells (Earle's balanced salt solution, $0.5 \%$ lactalbumin hydrolysate, $10 \%$ adult bovine serum, antibiotics), then adapted to secondary fetal bovine kidney cells (Earle's $199,0.5 \%$ lactalbumin hydrolysate, $10 \%$ adult bovine serum, antibiotics). The virus produced CPE and replicated in these cells as indicated by staining with fluorescein-labeled rabbit gamma globulin against the virus. The type of CPE observed after 24 passages was a rounding and loss of adherence of cells with formation of syneytia. Takahashi et al. (34) also used primary bovine kidney cells for the isolation of the Kakegawa strain of BCV (a field strain from the feces of a cow with epizootic diarrhea). CPE, characterized by syncytia and granularity of cells and positive immunofluorescence, became noticeable by Passage 8 .
Inaba et al. (15) and Sato et al. (27) utilized the continuous cell line, BEK-1 (Eagles's minimum essential medium, $10 \%$ tryptose phosphate broth, $10 \%$ bovine serum, antibiotics) derived from bovine embryonic kidney to grow the Mebus (cell cultureadapted, NCDV) strain of BCV. CPE first appeared at $3 \mathrm{~d}$ as cell rounding, which progressed to cell fusion, monolayer disintegration, and sloughing. After further passages viral yield ranged from $10^{4}$ to $10^{5}, 50 \%$ tissue culture infective dose $\left(\right.$ TCID $\left._{50}\right) / 0.1 \mathrm{ml}$. CPE could be specifically inhibited by antiserum to BCV and infected cells could be detected by immunofluorescent staining. Akashi et al. (1) then utilized this cell line to characterize the Kakegawa isolate of BCV, which had previously been adapted to primary bovine kidney cells. Hirano et al. (13) showed that the BEK-1 cell line could be used in a plaque assay for the Kakegawa strain of BCV. After a 90-min absorption time and a 48-h incubation period, clear plaques were visible without staining with neutral red.

Dea et al. (8) demonstrated that African green monkey kidney (Vero), MDBK, and porcine kidney-15 (PK-15) continuous cell lines (Eagle's minimal essential medium, Earle's salt, $0.584 \mathrm{~g}$ of glutamine/liter, with 10,5 , and $3 \%$, respectively, heat-inactivated FBS without gamma-globulin) were satisfactory for the isolation and multiplication of the Mebus strain of BCV. Several field isolates were also cultivated in Vero cells and then adapted to MDBK and primary bovine fetal kidney cells. CPE and positive immunofluorescent staining were observed in all cell lines. CPE consisted of cell rounding, detachment, and complete monolayer destruction after $96 \mathrm{~h}$. Viral yield varied between $10^{6}$ and $10^{7} \mathrm{TCID}_{\mathrm{s0}} / \mathrm{ml}$. Cells tested in which the virus did not produce CPE were embryonic bovine derma (EBD), embryonic bovine trachea (EBTr), human epitheloid carcinoma (HeLa), human epidermoid carcinoma (Hep2), African green monkey (BSC-1), Madin Darby Canine Kidney (MDCK), embryonic lamb kidney (LK), and mouse L cells. The MDBK cell line has also been useful for plaque and plaque-reduction assays. After a l-h adsorption time, use of an overlay with agarose and a 3-to-4-d incubation period, plaques were visible after staining with neutral red (10).

Laporte et al. $(19,20)$ and L'Haridon et al. (17) also reported the adaptation of a wild type BCV (G110 strain) from France to primary calf kidney (PCK) cells (Earle's medium, $0.5 \%$ lactalbumine, $0.1 \%$ yeast extract, 6\% FBS). There was no CPE and specific fluorescence appeared late, 8 to $12 \mathrm{~d}$ postinfection. After 12 passages in an established human rectal adenocarcinoma cell line (HRT-18) (RPMI 1640, 20\% FBS), high viral yields, in excess of $10^{7} \mathrm{TCID}_{50} / \mathrm{ml}$, were achieved but no CPE was observed. They also showed that the PCK-adapted virus multiplied in bovine skin cells, bovine lung cells, MDBK cells, and $\mathrm{K} 3$ pig kidney cell lines. There was no virus growth in other pig kidney lines, baby hamster kidney (BHK21), Chinese hamster ovary (CHO), or MDCK cell lines. The HRT-18 cell line was also useful for titration of the cell culture-adapted $\mathrm{G} 110$ and F15 strains of BCV in a 
plaque assay. Plaques appeared within 2 to $3 \mathrm{~d}$ as opalescent areas, which remained colourless after neutral red or crystal violet staining. (42)

Tektoff et al. $(35,36)$ also proved that HRT-18 (RPMI 1640, 20\% FBS), Vero (Medium 199, 5\% FBS), and MDBK (Eagle-Earle medium, 5\% FBS, $0.25 \mathrm{~g} /$ liter casein hydrolysate) cell lines were permissive to cell culture-adapted strains of BCV. Infectivity and viral morphogenesis were followed by transmission electron microscopy, hemadsorption and scanning electron microscopy, immunofluorescence, and hemagglutination (HA) assays.

The Mebus cell culture-adapted strain of BCV has also been propagated in the MA-321 strain of human embryonic lung fibroblasts (Eagle's minimum essential medium, $10 \%$ FBS). HA titers with rat or chicken erythocytes reached a peak at $72 \mathrm{~h}$ and remained stable until $144 \mathrm{~h}$ postinfection. At 4 to $5 \mathrm{~d} \mathrm{CPE}$ appeared as refractile, oval or rounded cells, with a cytoplasm rich in microvacuoles. Complete degeneration of cell monolayers was observed 6 to $10 \mathrm{~d}$ postinfection (12).

A porcine renal cell culture-adapted strain of $\mathrm{BCV}$ (SC-1) was grown in Passages 2 to 5 of primary fetal (3 to 4 mo. gestation) ovine renal cells (Eagle's minimum essential medium, 10 to $15 \%$ FBS). CPE was observed at 48 to $72 \mathrm{~h}$ postinoeulation as formation of syncytia. Virus replication was detected by hemadsorption of rat erythrocytes and cell culture supernatant HA titers of $1 / 64$ to $1 / 128(3)$. BCV has also been shown to replicate in calf testicle cells (23), and D2 bovine fetal spleen cells (7).

Organ culture of BCV has been achieved in two organ systems. Stott et al. (32) showed that the Mebus cell culture-adapted strain would produce hemagglutinating activity and replicated in 5- to 6-mo. gestation fetal bovine tracheal organ culture (Eagle's basal medium, $0.14 \%$ sodium bicarbonate, $0.09 \%$ bovine plasma albumin, $5 \%$ tryptose phosphate broth, antibiotics, HEPES buffer, $\mathrm{pH}$ 7.2). Hemagglutinin titers increased with viral passage. Positive immunofluorescence was first observed at $7 \mathrm{~d}$ and peaked at $21 \mathrm{~d}$ post-inoculation, and electron microscopic examination of culture fluids revealed typical coronavirus particles. No gross or histologic damage to the cilia was visible.

Bridger et al. (6) also demonstrated hemagglutinating activity and replication of a British isolate (passaged in tracheal organ culture) of BCV in 4.5- to 6-mo. gestation fetal bovine intestinal organ cultures. Hemagglutinating activity peaked at 24 to $48 \mathrm{~h}$ postinoculation, whereas immunofluorescence, detected solely in the columnar epithelial cells, was maximal at $24 \mathrm{~h}$. At 2 to $4 \mathrm{~d}$ postinoculation the columnar epithelium lost its normal morphology, becoming irregular and disorganized. Typical coronavirus particles were seen in extracellular fluids harvested 18 to $96 \mathrm{~h}$ postinoculation. Electron microscopic examination of inoculated cultures revealed evidence of viral replication and budding.

B. Enhancement of in vitro replication
Conditions for enhancing growth of cell cultureadapted strains of BCV in certain cell culture systems have been described. Dea et al. (8) showed that the factors important in increasing yield and appearance of CPE in Vero cells were a) a slightly acidic inoculum ( $\mathrm{pH}$ 6.5 to 7.0 ); b) growth in a basic medium ( $\mathrm{pH} 8.0$ to 8.5 ); c) exposure to hypertonic medium; d) polycation DEAE-dextran $(25 \mu \mathrm{g})$ treatment of cells; e) washing of cells with medium containing trypsin $(5 \mu \mathrm{g} / \mathrm{ml})$; and f) incubation of cells with dactinomycin $(0.01$ to $0.05 \mu \mathrm{g})$.

Storz et al. (31) also showed the importance of trypsin in the replication and cytopathogenicity of the cell culture-adapted $L 9$ strain of BCV. Trypsin treatment $(10 \mu \mathrm{g} / \mathrm{ml})$ accelerated CPE and size of plaques, facilitated cell fusion, improved the amount of cellreleased hemagglutinin, and increased the infectivity yields in bovine fetal thyroid (BFTy) and bovine fetal brain cells (BFB) (Eagle minimum essential medium, antibiotics, $10 \%$ heat-inactivated fetal calf or lamb serum). When virus was pretreated with trypsin or trypsin was present only during viral adsorption, plaque enhancement was not observed.

Trypsin was also important for replication of the Mebus strain of BCV in bovine embryonic lung cells (Eagle's minimal essential medium, $0.22 \%$ sodium bicarbonate, $20 \mathrm{~m} M$ HEPES buffer, $0.01 \%$ pyruvic acid, $0.029 \%$ L-glutamine, $10 \%$ FBS, antibiotics) (38). Toth showed that increased amounts of trypsin $(1,5$, or $10 \mu \mathrm{g} / \mathrm{mll}$ increased the susceptibility of bovine embryonic lung cells to BCV a millionfold.

Hirano et al. (13) found that when trypsin, at a final concentration of $5 \mu \mathrm{g} / \mathrm{ml}$, was added to both the viral diluent and the overlay medium, plaques increased in size and numbers on BEK-1 cells infected with the Kakegawa strain of BCV. This did not occur if $1 \%$ trypsin was added to either the viral diluent or the overlay medium alone.

Cyr-Coats and Storz (7) demonstrated that the celladapted BCV L9 strain could be induced to replicate noncytopathically in D2 bovine fetal spleen cells only in the presence of trypsin. The bovine fetal spleen cells were however nonpermissive for all wild-type BCV, even in the presence of trypsin.

The mechanism(s) whereby trypsin enhances coronavirus replication is not yet fully understood. Tryspin treatment of cells might promote attachment of virions by uncovering otherwise unavailable receptor sites. Trypsin treatment of virus might modify configurations of protein molecules in the virus envelope to render them more compatible with cellular receptor sites. Alternatively, trypsin may destroy a broadly active viral inhibitor produced by cells in culture, thereby allowing multiple rounds of viral replication $(4,9,14,38)$.

C. Animal inoculation

Bovine coronavirus can also be propagated by animal inoculation. This may be a useful, if not necessary, method of producing large pools of field BCV strains which may not otherwise propagate well in cell culture systems. The LY-138 strain of $\mathrm{BCV}$, first isolated in 
1965, was maintained by oral inoculation of conventional, colostrum-deprived calves for many years by this method (11).

Akashi et al. (2) serially passaged the Kakegawa strain of $\mathrm{BCV}$ in suckling mice, rats, and hamsters by inoculation with brain emulsions from infected laboratory animals. The Kakegawa strain, at Passage 10 in primary bovine kidney cell cultures, was inoculated intracerebrally and subcutaneously into the laboratory animals. Infected animals showed nervous symptoms, and died. The recovered virus could be clearly differentiated from mouse hepatitis virus by cross-neutralization tests.

The Mebus strain of BCV was also adapted to suckling mouse brain by Kaye et al. (16) and later by Gerna et al. (12), facilitating comparative serologic testing with human coronavirus strains.

D. Final remarks

Several cell types are permissive for the replication of cell culture-adapted strains of BCV and several cell lines allow the virus to be grown to high titer. Trypsin is useful for enhancing replication of cell culture-adapted strains of BCV. Field isolates of BCV have been propagated in primary bovine kidney and Vero cells. These cell types may be useful for virus isolation or virus quantitation, or both, from diagnostic samples. Several methods have been established for determination of BCV yields from cell or organ culture. These include enumeration of viral particles in culture supernatants by electron microscopy; determination of TCID $_{50}$ on BEK1, Vero, MDBK, PK-15, BEL, and HRT-18 cell lines; HA and hemadsorption assays with rat and chicken erythrocytes; direct or indirect immunofluorescent assays; and plaque assays on BEK-1, MDBK, BFT, BFTy, and HRT -18 cells.

In our laboratory we have successfully propagated NCDV BCV to high titers $\left(10^{\gamma} \mathrm{pfu} / \mathrm{ml}\right)$ in roller bottles of MDBK cells using pancreatin in the maintenance medium. We have also developed a plaque assay for $\mathrm{BCV}$ in these cells by adding pancreatin and DEAE to the agar overlay medium.

\section{REFERENCES}

1. Akashi, H.; Inaba, Y.; Miura, Y., et al. Properties of a coronavirus isolated from a cow with epizootic diarrhea, Vet. Microbiol. 5:265-276; 1980.

2. Akashi, H.; Inaba, Y.; Miura, Y., et al. Propagation of the Kakegawa strain of bovine coronavirus in suckling mice, rats and hamsters. Arch. Virol. 67:367-370; 1981 .

3. Barboi, G. H.; Pirvulescu, M. Le test d'inhibition de l'hemagglutination (IHA) pour le diagnostic de l'infection a coronavirus chez les bovins. Rev. Roum. Med.-Virol. 37:253-256; 1986.

4. Baron, S.; McKerlie, M. L. Broadly active inhibitor of viruses spontaneously produced by many cell types in culture. Infeet. Immun. $32: 449-453 ; 1981$.

5. Bosgiraud, C.; Nicolas, J. A. Pneumonie a coronavirus chez les bovine: A propos de deux observations. Rec. Med. Vet. 162:1085-1086; 1986.

6. Bridger, J. C.; Caul, E. O.; Egglestone, S. I. Replication of an enteric bovine coronavirus in intestinal organ cultures. Arch Virol. 57:43-51; 1978.

7. Cyr-Coats, K. St.; Storz, J. Bovine coronavirus cytopathic expression and plaque formation: host cell and virus strain determine trypsin dependence. 68th Annual Conference of Research Workers in Animal Disease; 1987, November 16-17, Chicago IL., Abstract 83.
8. Dea, S.; Roy, R. S.; Begin, M. E. Bovine coronavirus isolation and cultivation in continuous cell lines. Am. J. Vet. Res. 41:30-38; 1980,

9. Debiaggi, M.; Perduca, M.; Romero, E., et al, Phosphatidyl-serine inhibition of OCA3 and NCDCV coronavirus infectivity. Microbiologica 8:313-317; 1985

10. Deregt, D.; Crouch, C. F.; Sabara, M., et al. Preliminary studies of a bovine coronavirus (BCV) antigen responsible for neutralization. Proceeding, Fourth International Symposium on Neonatal Diarrhea, October 3-5, Saskatoon, Saskatchewan, Canada, Veterinary Infectious Disease Organization, 1984:117-132.

11. Doughri, A. M.; Storz, J.; Hajer, I, et al. Morphology and morphogenesis of a coronavirus infecting intestinal epithelial cells of newborn calves. Exp. Mol. Pathol. 25:355-370; 1976.

12. Gerna, G.; Cereda, P. M.; Revello, M. G., et al. Antigenic and biological relationships between human coronavirus $\mathrm{OC} 43$ and neonatal calf diarrhoea coronavirus. J. Gen. Virol. 54:91-102; 1981.

13. Hirano, N.; Sada, Y.; Tuchiya, K., et al. Plaque assay of bovine coronavirus in BEK-1 cells. Jpn. J. Vet. Sci. 47:679-681; 1985.

14. Hughes T. K.; Blalock J. E.; MeKerlie M. L., et al. Cell-produced viral inhibitor: possible mechanism of action and chemical composition. Infect. Immun. 32:454-457; 1981.

15. Inaba, Y,; Sato, K.; Kurogi, H., et al. Replication of bovine coronavirus in cell line BEK-1 culture. Arch. Virol. 50:339-342; 1976.

16. Kaye, H. S.; Yarbrough, W. B.; Reed, C. J. Calf diarrhoea coronavirus. Lancet II:509; 1975.

17. L'Haridon, R.; Scherrer, R.; Vautherot, J. F., et al. Adaptation d'un isolement de coronavirus enterique bovine a la culture cellulaire et caracterisation de la souche obtenue. Ann. Rech. Vet. 12:243-251; 1981.

18. Langpap, T. J.; Bergeland, M. E.; Reed, D. E. Coronaviral enteritis of young calves: virologic and pathologic findings in naturally occurring infections. Am. J. Vet. Res. 40:1476-1478; 1979.

19. Laporte, J.; L'Haridon, R.; Bobulesco, P. In vitro culture of bovine enteritic coronavirus (BEC). In: Bricout F.; Pensaert M.; Flewett T. H., et al., compilers. Enterites virales chex l'homme et l'animal; viral Enteritis in humans and animals. Thiverval-Grignon, France: I'INSERM 1979; 90:99-102.

20. Laporte, J.; Bobulesco, P.; Rossi, F. Une lignee cellulaire particulierement sensible a la replication du coronavirus enteritique bovin: les cellules HRT 18. C. R. Acad. Sci. 290:623-626, Serie D; 1980.

21. MeNulty, M. S.; Bryson, D. G,; Allan, G. M., et al. Coronavirus infection of the bovine respiratory tract. Vet. Microbiol. 9:425-434; 1984.

22. Mebus, C. A.; Stair, E. L.; Rhodes, M. B., et al. Neonatal calf diarrhea: propagation, attenuation, and characteristics of a coronavirus-like agent. Am. J. Vet. Res. 34:145-150; 1973.

23. Moussa, A. Incurved disc from particles associated with a bovine coronavirus growing in Vero and calf testicle cell cultures. Proceeding, VII International Congress of Virology, August 9-14, Edmonton, Alberta Canada, Abstract R11.11, 1987:110.

24. Phillips, R. W.; Case, G. L. Altered metabolism, acute shock, and therapentic response in a calf with severe coronavirus-induced diarrhea. Am. J. Vet. Res. 41:1039-1044; 1980.

25. Reynolds, D. J. Coronavirus replication in the intestinal and respiratory tracts during infection of calves. Ann. Rech. Vet. 14:445-446; 1983.

26. Saif, L. J.; Redman, D. R.; Moorhead, P. D., et al. Experimentally induced coronavirus infections in calves: viral replication in the respiratory and intestinal tracts. Am. J. Vet. Res. 47:1426-1432; 1986.

27. Sato, K.; Inaba, Y.; Kurogi, H., et al. Physico-chemical properties of calf diarrhea coronavirus. Vet. Microbiol. 2:73-81; 1977.

28. Sharpee, R. L.; Mebus, C. A.; Bass, E. P. Characterization of a calf diarrheal coronavirus. Am. J. Vet. Res. 37:1031-1041; 1976.

29. Siddell, S.; Wege, H.; Ter Melullen, V. The biology of coronaviruses. J. Gen. Virol. 64:761-776; 1983.

30. Stair, E. L.; Rhodes, M. S.; White, R. G., et al. Neonatal calf diarrhea: purification and electron microscopy of a coronavirus-like agent. Am. J. Vet. Res. 33:1147-1156; 1972.

31. Storz, J.; Rott, R.; Kaluza, G. Enhancement of plaque formation and cell fusion of an enteropathogenic coronavirus by trypsin treatment. Infect. Immun. 31:1214-1222; 1981 .

32. Stott, E. J.; Thomas, L. H.; Bridger. J. C., et al. Replication of a bovine coronavirus in organ cultures of foetal trachea. Vet. Microbiol. 1:65-69; 1976.

33. Sturman, L. S.; Homes, K. V. The molecular biology of coronaviruses. Adv. Virus Rées. 28:35-112; 1983. 
34. Takahashi, E.; Inaba, Y.; Sato, K., et al. Epizootic diarrhoea of adult cattle associated with a coronavirus-like agent. Vet. Microbiol. 5:151-154; 1980 .

35. Tektoff, J.; Cauvergne, M.; Durafour, M., et al. Propagation of bovine coronavirus on Vero cell line: electron microscopic studies. In: International Symposium on Enteric Infections in Man and Animals: Standardization of Immunological Procedures. Dublin Ireland Develop. Biol. Standard. 53:299-310; 1982. Basel; S. Karger; 1983.

36. Tektoff, J.; Dauvergne, M.; Durafour, M., et al. Propagation of bovine enteritic coronavirus in three cell systems: electron microscopic studies. Proceeding of the Fourth International Symposium on Neonatal Diarrhea. Veterinary Infeetious Disease Organization; 1984:134-153.

37. Thomas, L. H.; Gourlay, R. N.; Stott, E. J., et al. A search for new microorganisms in calf pneumonia by the inoculation of gnotobiotic calves. Res. Vet. Sci. 33:170-182; 1982.

\footnotetext{
${ }^{1}$ Scientific Industries, Inc., Bohemic, NY

"National Appliance Co., Portland, OR

${ }^{3}$ Queue Systems, Parkersburg. WV

* Precision Scientific Co. . Chicago, IL

"Baker Co., Inc., Sanford, MA

*Weaton. Millville, NJ

'Republic Seitz Filter Corp., Millale, CT

* Millipore, Bedford, MA

Squibb \& Sons. Inc., Princeton, NJ

to Pfizer. Inc, , New York, NY
}

38. Toth. T. E. Trypsin-enhanced replication of neonatal calf diarrhea coronavirus in bovine embryonic lung cells. Am. J. Vet. Res. $43: 967-972 ; 1982$

39. Tyrrell, D. A. J.; Almeida, J. D.; Berry, D. M.; Coronaviruses. Nature $220: 650 ; 1968$.

40. Tryrrell, D. A. J.; Almeida, J. D.; Cunningham, C. H., et al. Coronaviridae. Intervirology 5:76-82; 1975.

41. Tryrrell, D. A. J.; Alexander, J. D.; Almeider, J. D., et al. Coronaviridae: second report. Intervirology 10:321-328; 1978.

42. Vautherot, J. Plaque assay for titration of bovine enteric coronavirus. J. Gen. Virol. 56:451-455; 1981 .

43. Weller, T. H.; Enders, J. F; Robbins, F. C., et al. Studies on the cultivation of poliomyelitis viruses in tissue culture. I. The propagation of poliomyelitis viruses in suspended cell culture of various human tissues. J. Immunol. 69:645-671; 1952.

${ }^{11}$ NB Co. Biochemicals, Cleveland, $\mathrm{OH}$

${ }^{12}$ GIBCO, Inc., Grand Island, NY

"3isher Scientific Co., Fairlawn, NJ

${ }^{4}$ Matheson Coleman and Bell, Los Angeles, CA

is Merck \& Co., Inc., Rahway, NJ

${ }^{16}$ DIFCO Laboratories, Detroit, MI

1 Costar, Cambridge, MA

18 Falcon, Becton Dickinson Co., Oxnard, CA

18 Salisbury Laboratories, Charles City, IA 